\title{
Horseradish Essential Oil as a Promising Anti-Algal Product for Prevention of Phytoplankton Proliferation and Biofouling
}

\author{
István Bácsi ${ }^{1, *(\mathbb{D}}$, Sándor Gonda ${ }^{2}$ (), Zsuzsanna Nemes-Kókai ${ }^{3,4,5}$, Viktória B-Béres ${ }^{3}$ and Gábor Vasas ${ }^{2}$ \\ 1 Department of Hydrobiology, University of Debrecen, Egyetem tér 1, H-4032 Debrecen, Hungary \\ 2 Department of Botany, University of Debrecen, Egyetem tér 1, H-4032 Debrecen, Hungary; \\ gondasandor@gmail.com (S.G.); vasas.gabor@science.unideb.hu (G.V.) \\ 3 Centre for Ecological Research, Institute of Aquatic Ecology, Department of Tisza Research, Bem tér 1, \\ H-4026 Debrecen, Hungary; kokai.zsuzsanna@ecolres.hu (Z.N.-K.); beres.viktoria@gmail.com (V.B.-B.) \\ 4 Department of Ecology, University of Debrecen, Egyetem tér 1, H-4032 Debrecen, Hungary \\ 5 Pál Juhász-Nagy Doctoral School of Biology and Environmental Sciences, University of Debrecen, Egyetem \\ tér 1, H-4032 Debrecen, Hungary \\ * Correspondence: istvan.bacsi@gmail.com; Tel.: +36-52-512-900 (ext. 22634)
}

check for

updates

Citation: Bácsi, I.; Gonda, S.;

Nemes-Kókai, Z.; B-Béres, V.;

Vasas, G. Horseradish Essential Oil as

a Promising Anti-Algal Product for

Prevention of Phytoplankton

Proliferation and Biofouling. Plants

2021, 10, 1550. https://doi.org/

10.3390/plants10081550

Academic Editors: Sheng-Yang Wang and K.J. Senthil Kumar

Received: 13 July 2021

Accepted: 26 July 2021

Published: 28 July 2021

Publisher's Note: MDPI stays neutral with regard to jurisdictional claims in published maps and institutional affiliations.

Copyright: (c) 2021 by the authors. Licensee MDPI, Basel, Switzerland. This article is an open access article distributed under the terms and conditions of the Creative Commons Attribution (CC BY) license (https:/ / creativecommons.org/licenses/by/ $4.0 /)$.

\begin{abstract}
Increased proliferation of algae is a current problem in natural and artificial water bodies. Controlling nutrients is the most sustainable treatment of increased algal proliferation, however in certain cases, it is not sufficiently available, or it does not provide results fast enough. Chemicals derived from natural sources, which could be effective in low concentrations and are biodegradable, may have an advantage over conventional chemical treatments. The main aim of the present study was to investigate the anti-cyanobacterial and anti-algal properties of allyl-isothiocyanate-containing essential oil produced from horseradish roots with a complex approach of the topic: on laboratory strains of cyanobacteria and eukaryotic algae, on microcosms containing natural phytoplankton assemblages, and on semi-natural biofilms. The results show that acute treatment can significantly reduce the viability of all the tested cyanobacteria and eukaryotic algae. Results of microcosm experiments with natural phytoplankton assemblages show that horseradish essential oil from $7.1 \times 10^{-6 \%}(v / v)$ is applicable to push back phytoplankton proliferation even in natural assemblages. The individual number in the biofilm was dropped down to one-fifth of the original individual number, so $7.1 \times 10^{-6 \%}(v / v)$ and higher concentration of the essential oil can be considered as a successful treatment against biofouling.
\end{abstract}

Keywords: horseradish essential oil; cyanobacteria; eukaryotic algae; phytoplankton; biofilm

\section{Introduction}

Increased proliferation of algae is a current problem in natural as well as in established water bodies (beaches, fishponds, urban ponds, pools, fountains, etc.). The most obvious consequence of the mass development of algae is that they cause difficulties in water usage in many areas (recreation, fisheries, agriculture, industry, and drinking water [1]). Phytoplankton blooms often come along with the production of unpleasant odor, which could be problematic in urban environments, but more importantly, blooms can cause oxygen depletion in water bodies, they may be toxic (due to the production of biochemically active secondary metabolites); consequently, blooms can cause perish of other organisms, leading to changes in diversity [2].

In addition to planktic algae, benthic algae can also appear with high biomass in ornamental ponds, pools, fountains, wells as part of biofouling (microfouling [3]). Biofouling is a strongly disadvantageous phenomenon that may cause several problems on artificial surfaces immersed in water [4]. Algae may appear even in land conditions (walls, fences, roads) with the presence of adequate humidity, causing aesthetic, moreover economic, or even health problems. 
The decontamination of artificial pools and fountains seems to be a simpler task, as in these cases, there are no living organisms to be taken into account. However, human health impacts and the environmental impacts of effluents after chemical treatment should also be considered in these cases. The situation is more difficult in the case of semi-natural or natural water bodies (beaches, fishponds, urban ponds), where the presence of living communities must also be taken into account when developing measures designed to reduce the growth of algae.

There are many chemical methods (compounds) that are used to reduce the proliferation of phytoplankton in water bodies either directly via growth inhibition or indirectly by a decrease in nutrient concentration [2]. Similarly, paints and coatings containing toxic materials are commonly used to control biofouling [4].

Metal (aluminum, iron, or copper)-containing compounds are used either as direct algaecides or as the most common coagulants for removal of nutrients (mainly phosphorous) from waters in many areas of the water industry [5-12]. Besides copper, antifouling paints or coatings usually contained lead, arsenic, or mercury [13]. Calcium-containing and clay compounds [14-17] are also usually used as inorganic coagulants. The best-known metalcontaining antifoulants are organotin compounds [18]. The main problem of the application of metal-containing compounds is the possible toxic effect on non-target organisms and the resulting, also possibly toxic sludge [2,19].

Other possible methods using chemicals are able to generate different reactive oxygen species (ROS) upon light irradiation. Hydrogen peroxide, phtalocyanines [20,21], titaniumdioxide [2], chlorine [22], hypochlorite or chlorine-dioxide [23], permanganate [24-26] or ozone [27] are the most known compounds used for generating ROS. Cyanobacteria seem to be significantly more sensitive to the presence of ROS than other aquatic organisms [20,21], which could be advantageous in controlling cyanobacterial blooms. There are some disadvantages of these compounds too: toxic effects to non-target organisms, insufficient solubility [2], formation of undesirable by-products, or unpleasant odor occurrences [17].

The third group of chemicals used in algal proliferation control is the group of organic herbicides. Diuron (3-(3,4-dichlorophenyl)-1,1-dimethylurea) [28] and Endothall (3,6-endoxohexahydrophthalic acid) are well known and relatively widely used herbicides in aquatic habitats [29]. Unfortunately, the use of neither compound is problem-free [30-32].

Chemical compounds derived or extracted from living organisms seem to be a promising alternative among methods against undesirable algal proliferation [2]. Over the last few decades, many compounds have been isolated from microalgae, macroalgae, and aquatic microorganisms [33-35] or from aquatic (marine) invertebrates [3]. Recently, plant metabolites as biocides came to the fore [36] since plant secondary metabolites, such as essential oils and herb extracts, have revealed relatively powerful broad-spectrum antimicrobial activities [37-39]. One of the plants as a promising source of antimicrobial metabolites is Armoracia rusticana, commonly known as horseradish.

Horseradish has been cultivated for a long time and is used primarily in the food industry, but more and more research data highlight other possible uses of this plant [40]. Glucosinolates belong to the most important secondary metabolites of horseradish [41]. These compounds are part of the plant's defense mechanisms: when damage is done to the plant, hydrolysis of glucosinolates by the enzyme myrosinase is triggered. The quality of hydrolysis products depends on many factors. Isothiocyanates (ITCs) are the default main products [42-44]. ITCs are promising antimicrobial agents: their antibacterial, antiprotozoal [45-48], and antifungal [49] effects have been reported. Enzyme inactivation [46], uncoupling action of oxidative phosphorylation [45], oxidative stress, and DNA damage [50] are in the background of antimicrobial activity of isothiocyanates.

The main aim of the present study was to investigate the anti-algal properties of allyl-isothiocynate (AITC)- and phenetyl-isothiocyanate (PEITC)-containing essential oil produced from horseradish roots. The goal was a complex approach to the topic: model organisms representing potential water bloom-forming species were applied in laboratory experiments, as well as natural phytoplankton assemblages in microcosms and biofouling 
on artificial surfaces also were studied. This complex approach provides the opportunity to evaluate the possible differences in model systems and in actual assemblages and to study the anti-algal, anti-bloom-forming, and antifouling effects of the horseradish essential oil. We aimed to answer the following study questions:

How sensitive are laboratory strains of common, potentially bloom-forming cyanobacteria and eukaryotic algae to horseradish essential oil? What are the concentrations and exposition times causing 50\% growth inhibition?

How does horseradish essential oil extract work in a more life-like environment? What are the effects on natural algal assemblages in microcosms?

How effective is the horseradish essential oil extract treatment on semi-natural benthic algal communities (algal biofilms, antifouling effect)?

\section{Results}

\subsection{Laboratory Experiments}

Considering growth, $1.8-3.6 \times 10^{-6 \%}$ essential oil caused stronger growth inhibition of the filamentous cyanobacterium Cylindrospermopsis raciborskii cultures than to the unicellular ones (Synechococcus elongatus and Microcystis aeruginosa) after 7 days of exposition. However, higher concentrations $\left(14.3-28.6 \times 10^{-6 \%}\right)$ caused weaker growth inhibition in cultures of the filamentous species than in cultures of the unicellular ones (Figure 1a-c). On the basis of $\mathrm{EC}_{50}$ values (both for the fourth and seventh days), Synechococcus showed higher tolerance against horseradish essential oil than the other two cyanobacterial species (Table 1). There were no significant differences among $\mathrm{EC}_{50}$ values calculated for the fourth and seventh days of either cyanobacterial species.

The flagellated, salt-tolerant (or halophillic) green alga Dunaliella salina showed the highest sensitivity among eukaryotic algae (Figure 1d). Stronger growth inhibition occurred on the fourth and seventh day for the cell wall-less Cryptomonas ovata than for the coccoid green alga Chlorella sorokiniana (Figure 1e,f), but more or less similar $\mathrm{EC}_{50}$ values were calculated (Table 2). The unicellular Chlorococcum sp. and the coenobial Desmodesmus communis were the most tolerant ones among eukaryotic algae, only $7.1 \times 10^{-6} \%$ or more horseradish essential oil caused permanent growth inhibition, without observable growth regeneration (Figure $1 \mathrm{~g}, \mathrm{~h}$ ). Increasing $\mathrm{EC}_{50}$ values from day 7 to day 14 indicates increasing tolerance in the second week of exposure in the case of the cryptomonad and the different green algae (except $D$. salina; Table 1$)$.

Table 1. Horseradish essential oil concentrations ( $\left.\times 10^{-6} \mathrm{v} / \mathrm{v} \%\right)$ causing $50 \%$ growth inhibition on the $4^{\text {th }}, 7^{\text {th }}$, and $14^{\text {th }}$ day of the exposition based on chlorophyll-a content of the cultures. Mean values and standard deviations are indicated $(n=3)$.

\begin{tabular}{cccc}
\hline Strains & \multicolumn{2}{c}{$\mathbf{E C}_{\mathbf{5 0}}\left(\times \mathbf{1 0}^{-\mathbf{6}} \mathbf{v} / \mathbf{v}\right.$ \% Horseradish Essential Oil $)$} \\
$\mathbf{4}^{\text {th }} \mathbf{D a y}$ & $7.66 \pm 2.26$ & $7.95 \pm 0.48$ & $\mathbf{1 4}^{\text {th }} \mathbf{D a y}$ \\
\hline Synechococcus elongatus & $7.67 \pm 0.25$ & $5.07 \pm 0.38$ & - \\
Microcystis aeruginosa & 4.97 & $4.13 \pm 3.07$ & - \\
Cylindrospermopsis raciborskii & $4.77 \pm 2.87$ & $1.47 \pm 0.08$ & - \\
Dunaliella salina & $1.33 \pm 0.07$ & $1.63 \pm 0.47$ & $2.07 \pm 0.39$ \\
Cryptomonas ovata & $1.81 \pm 0.41$ & $1.67 \pm 0.02$ & $1.77 \pm 0.05$ \\
Chlorella sorokiniana & $1.57 \pm 0.05$ & $2.69 \pm 0.12$ & $2.81 \pm 0.05$ \\
Chlorococcum sp. & $2.37 \pm 0.49$ & $4.17 \pm 1.21$ & $4.76 \pm 0.27$ \\
Desmodesmus communis & $5.67 \pm 0.24$ & & \\
\hline
\end{tabular}



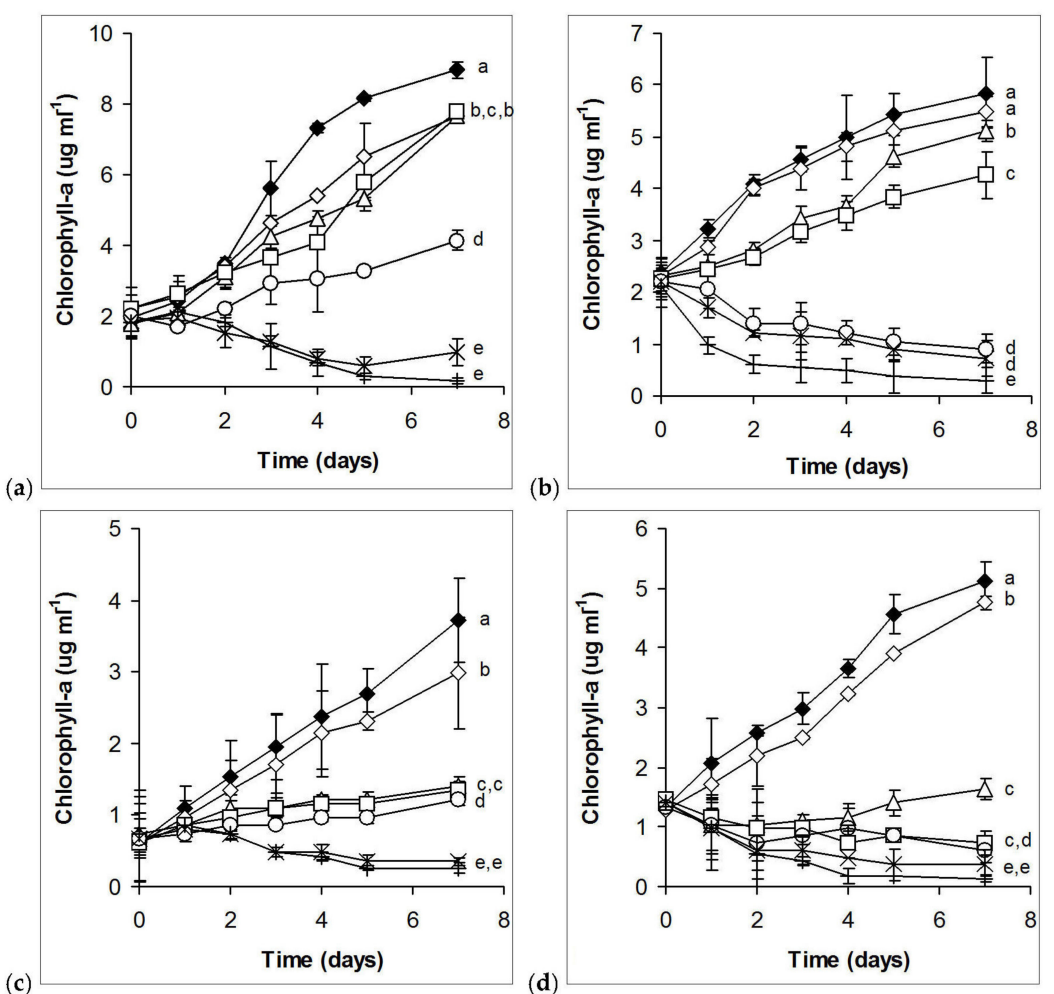

(b)
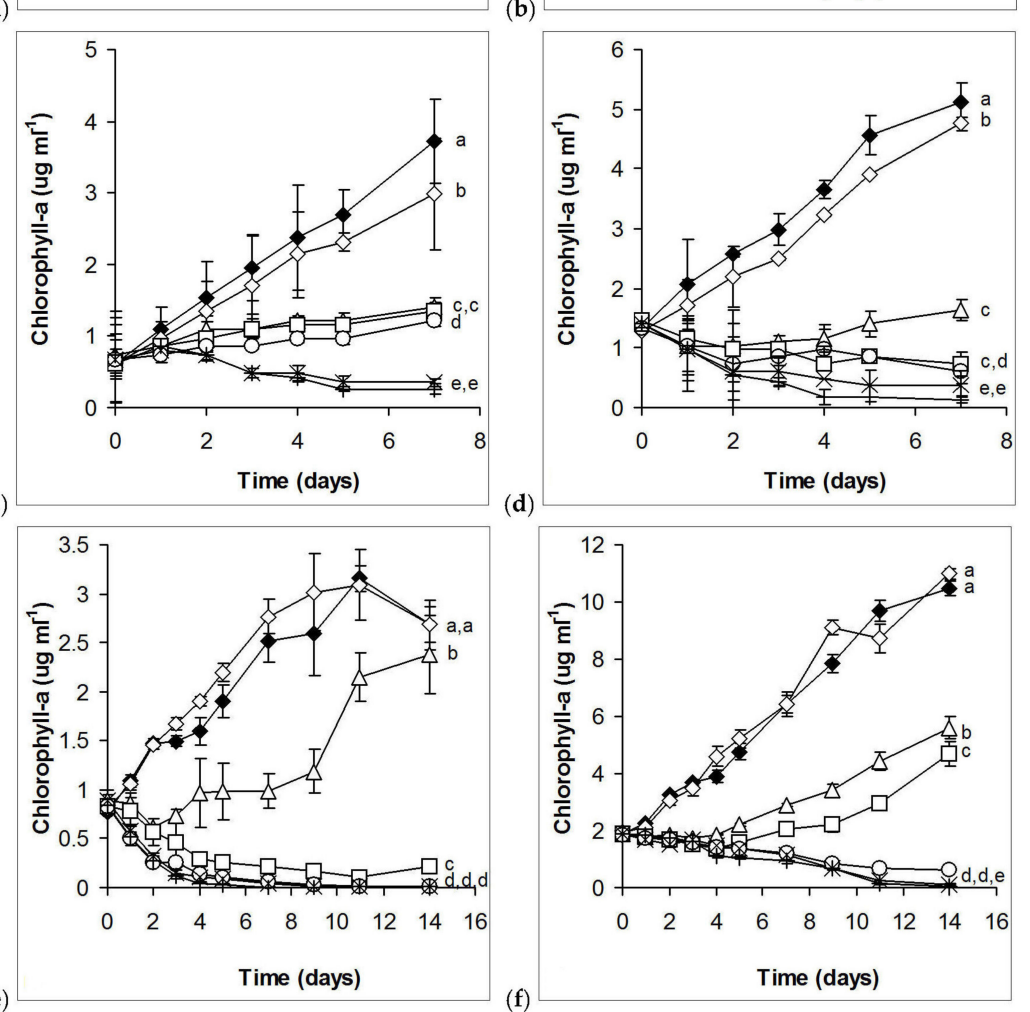

(e)
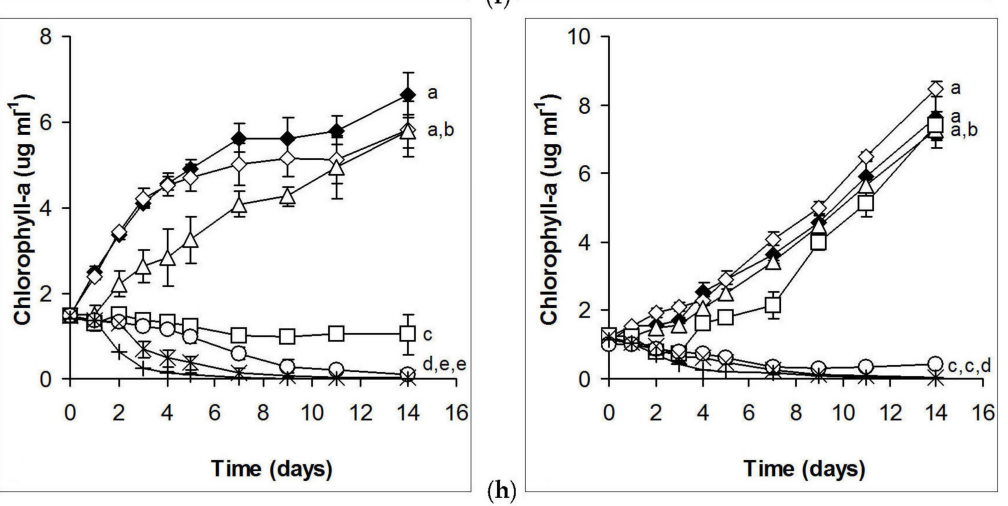

Figure 1. Growth of cyanobacteria and eukaryotic algae in control and horseradish essential oiltreated cultures. (a): Synechococcus elongatus; (b): Microcystis aeruginosa; (c): Cylindrospermopsis raciborskii; (d): Dunaliella salina; (e): Cryptomonas ovata; (f): Chlorella sorokiniana; (g): Chlorococcum sp.; (h): Desmodesmus communis. Black diamonds: control; empty diamonds: $28.6 \times 10^{-6} \%$ (v/v) ethanol; empty triangles: $1.8 \times 10^{-6}$; empty squares: $3.6 \times 10^{-6}$; empty circles: $7.1 \times 10^{-6}$; exes: $14.3 \times 10^{-6}$; plus signs: $28.6 \times 10^{-6} \%(\mathrm{v} / \mathrm{v})$ horseradish essential oil. Mean values \pm standard deviations are plotted $(n=3)$. Treatments not sharing the same lowercase letters are significantly different $(p<0.05)$. 
Although the lower sensitivity of cyanobacteria is not entirely obvious on the basis of the extent of growth inhibitions on certain days, $\mathrm{EC}_{50}$ values clearly indicate that cyanobacteria have higher tolerance against horseradish essential oil than eukaryotic algae. On the other hand, it has to be emphasized that growth regenerations also occurred in the case of green algae from the fourth day or later in cultures treated with lower concentrations $\left(1.8-3.6 \times 10^{-6 \%}\right)$, as was already mentioned above.

\subsection{Phytoplankton Assemblages in Microcosm Experiments}

Physical-chemical parameters changed similarly in control and in essential oil-treated assemblages (data not shown). Volume losses because of evaporation were below $1 \%$ in all microcosms throughout the experiment. Relative abundances of zooplankton species (mainly rotifers) and protozoan grazers (mainly ciliates) did not reach $2 \%$ of all the observed specimens during the experiments.

Quantitative changes in phytoplankton assemblages were assessed on the basis of chlorophylla content changes. Ethanol used to dilute the essential oil alone did not significantly affect the chlorophyll content, nor did essential oil concentrations in the range of $1.8-3.6 \times 10^{-6} \%$ (Figure 2). Higher essential oil concentrations (ranging $7.1-28.6 \times 10^{-6} \%$ ) resulted in significantly lower chlorophyll-a content compared to the control and from other treatments $(p<0.01$; Figure 2). However, it should be noted that chlorophyll-a content increased even in the presence of the highest essential oil concentration (Figure 2). $\mathrm{EC}_{50}$ values were $26.67 \pm 2.51 \times 10^{-6} \%$ for the $4^{\text {th }}$ day; $25.43 \pm 4.46 \times 10^{-6} \%$ for the $7^{\text {th }}$ day, and $83.83 \pm 32.21 \times 10^{-6} \%$ for the $14^{\text {th }}$ day. Significant $(p<0.05)$ increase in $\mathrm{EC}_{50}$ to the $14^{\text {th }}$ day indicates decreasing the sensitivity of the assemblages, regeneration of phytoplankton growth.

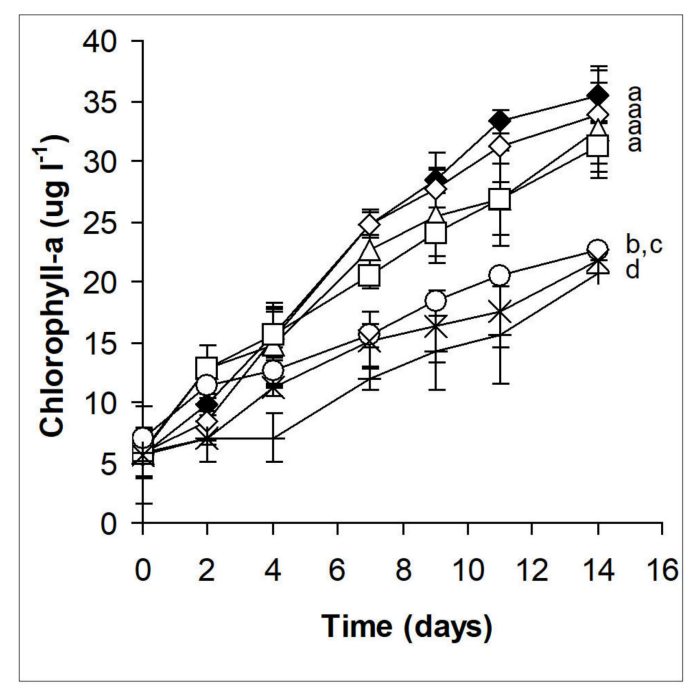

Figure 2. Quantitative changes of phytoplankton in microcosm experiments based on chlorophyll-a content as a result of horseradish essential oil treatment. Black diamonds: control; empty diamonds: $28.6 \times 10^{-6} \%(\mathrm{v} / \mathrm{v})$ ethanol; empty triangles: $1.8 \times 10^{-6}$; empty squares: $3.6 \times 10^{-6}$; empty circles: $7.1 \times 10^{-6}$; exes: $14.3 \times 10^{-6}$; plus signs: $28.6 \times 10^{-6} \%(\mathrm{v} / \mathrm{v})$ horseradish essential oil. Mean values \pm standard deviations are plotted $(n=3)$. Treatments not sharing the same lowercase letters are significantly different $(p<0.05)$.

Compositional changes were assessed on the basis of relative abundance changes of the main taxonomical groups. The most commonly observed genera of all individual taxa are shown in Table S1. The most striking change was the significant decrease in the relative abundance of Cyano 1 group to the seventh day of the exposure in assemblages treated with $3.6 \times 10^{-6} \%$ or higher essential oil concentrations $(p<0.01$; Figure $3 a)$. Although some extent of recovery to the $14^{\text {th }}$ day could be observed, the relative abundance of the Cyano 1 group remained significantly lower $(p<0.01)$ in certain essential oil treatments than in other assemblages (Figure 3a). The other group of cyanobacteria represented by low relative 
abundance (Cyano 2 group) was not sensitive to the presence of the horseradish essential oil (Figure 3b). Significant decreases in the relative abundances of diatoms (Diatom 1 and 2 groups) to the $14^{\text {th }}$ day are also worth mentioning $(p<0.05$; Figure $3 c, d)$.
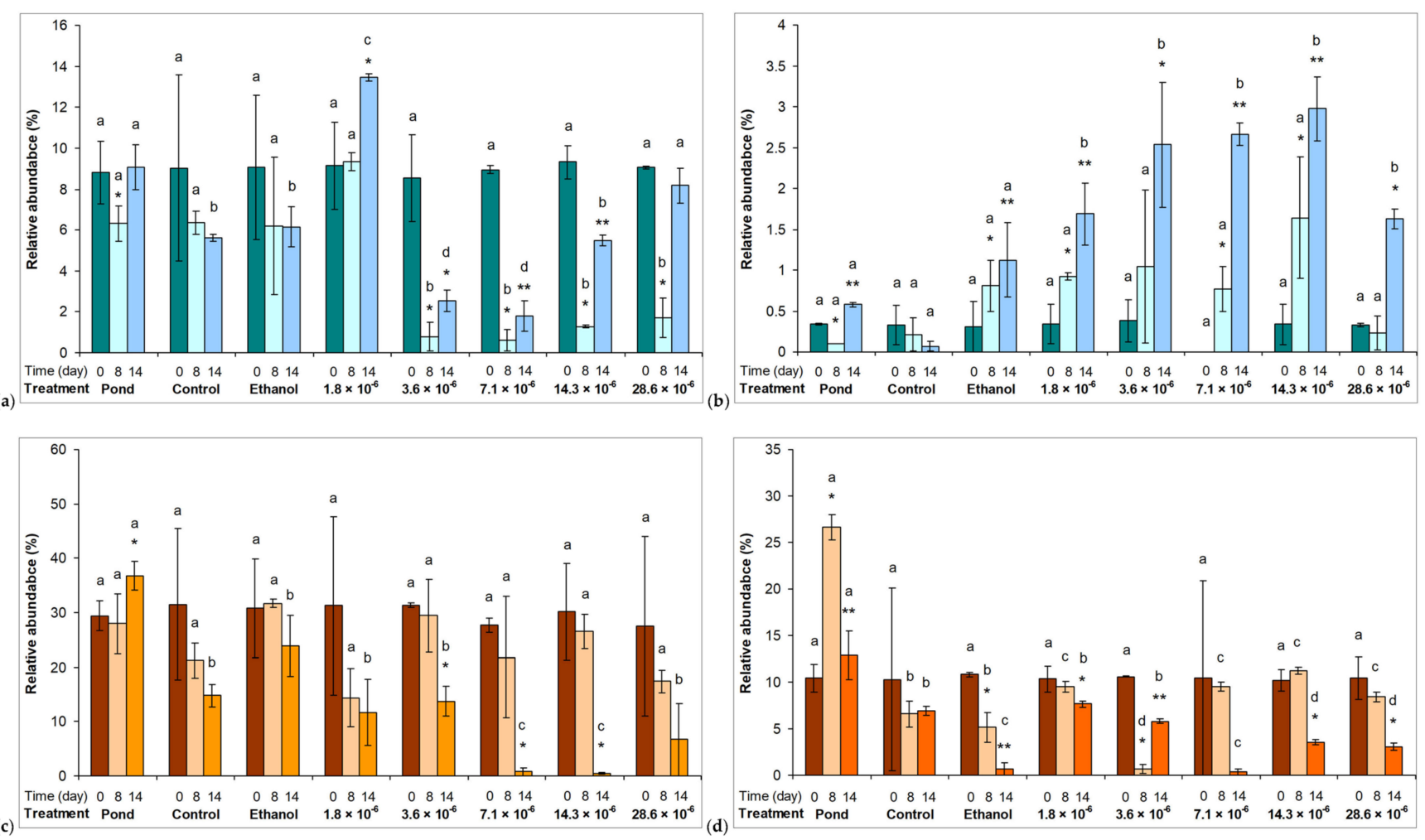

Figure 3. Relative abundances of the main cyanobacterium ((a,b); Cyano 1 - Synechococcales and 2 - Chroococcales) and diatom (c,d); Diatom 1 - Bacillariophyceae and 2 - Mediophyceae) groups in the pond, in control and in treated microcosm assemblages. Control: untreated microcosm. Ethanol: the microcosm contained $28.6 \times 10^{-6} \%(\mathrm{v} / \mathrm{v})$ ethanol. 0,8 , and 14 are the sampling days; $1.8-28.6 \times 10^{-6}$ are the applied horseradish essential oil concentrations (\%, v/v; dissolved in ethanol). Mean values \pm standard deviations are plotted $(n=3)$. Significant differences on a given day among treatments are indicated with different lowercase letters. Significant differences among days within a treatment are indicated with asterisks.

The dominant green algae were not sensitive to the presence of the horseradish essential oil. Their abundances showed increasing tendencies regardless of the applied concentrations. In fact, their relative abundances were higher in essential oil-treated assemblages (Figure $4 a-d)$. 

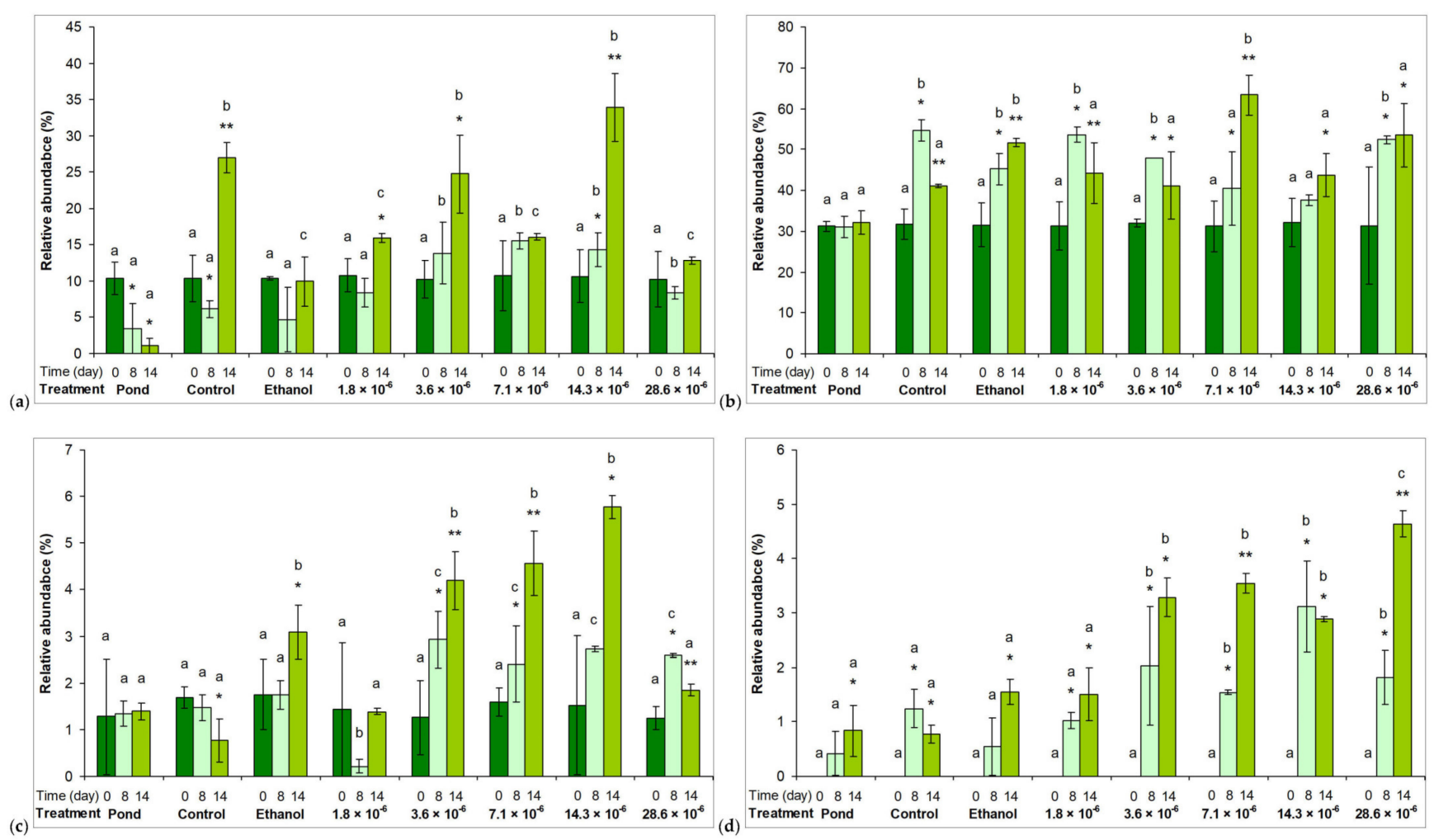

Figure 4. Relative abundances of the main green algae groups ((a-d); Green 1 - Trebouxiophyceae, 2 - Chlorophyceae, 3 - Conjugatophyceae, and 4 - Carophyceae + Klebsormidiophyceae) in the pond, in control and in treated microcosm assemblages. Control: untreated microcosm. Ethanol: the microcosm contained $28.6 \times 10^{-6} \%(\mathrm{v} / \mathrm{v})$ ethanol. 0,8 , and 14 are the sampling days; $1.8-28.6 \times 10^{-6}$ are the applied horseradish essential oil concentrations (\%, v/v; dissolved in ethanol). Mean values \pm standard deviations are plotted $(n=3)$. Significant differences on a given day among treatments are indicated with different lowercase letters. Significant differences among days within a treatment are indicated with asterisks.

\subsection{Benthic Assemblages on Artificial Surfaces}

Development of the natural benthic assemblages was unhindered, and green algae appeared in greater quantities alongside brown diatoms to the $5^{\text {th }}-6^{\text {th }}$ week of the experiment (Figure S1a). The lowest concentration of horseradish essential oil $\left(1.8 \times 10^{-6} \%\right)$ did not prevent the development of the biofilm (Figure S1b); however, no significant amount of green algae seemed to appear. Higher concentrations $\left(7.1 \times 10^{-6}\right.$ and $\left.28.6 \times 10^{-6} \%\right)$ inhibited the formation of the biofilm, although not completely prevented it. Based on the color of the biofilms, it was assumed that green algae and cyanobacteria may have been present in larger amounts at treatments $7.1 \times 10^{-6}$ and $28.6 \times 10^{-6} \%$ (Figure S1c,d).

Microscopic examinations supported the "macroscopic" observations of biofilm development. Quantitative data also showed that the lowest used concentration of horseradish essential oil did not affect biofilm development, the number of individuals per unit surface area $\left(1 \mathrm{~cm}^{2}\right)$ did not show a significant difference in the $1.8 \times 10^{-6} \%$ essential oiltreated culture compared to the control (Figure 5a). However, the next used concentration $\left(7.1 \times 10^{-6} \%\right)$ caused about $82 \%$ inhibition of biofilm development. Further increase in horseradish essential oil concentration $\left(28.6 \times 10^{-6} \%\right)$ did not cause significant difference compared to $7.1 \times 10^{-6} \%$ treatment ( $80.5 \%$ inhibition; Figure $\left.5 a\right)$. $\mathrm{EC}_{50}$ on the $6^{\text {th }}$ week was $5.2 \pm 0.9 \times 10^{-6} \mathrm{v} / \mathrm{v} \%$ horseradish essential oil.

The data on the composition of the biofilms only partially supported our assumptions based on their color change. In control biofilms, according to our assumption, the appearance of the green color was indeed the result of an increase in the proportion of green algae: their estimated proportion in the inoculum of around $10 \%$ increased to almost $19 \%$ under control conditions (Figure $5 \mathrm{~b}$ ). The species composition of the green algae did not change significantly during the 6 weeks: Tetradesmus obliquus was the dominant green 
alga species also in the mature biofilm, as it was in the original biofilm used for inoculation. The proportion of green algae decreased significantly $(p<0.05$; from $18.7 \%$ to $2.8 \%$; Figure 5$)$ at the lowest applied horseradish essential oil concentration $\left(1.8 \times 10^{-6 \%} \%\right)$. The niches freed during the fall of green algae were filled by cyanobacteria and diatoms. The proportion of both groups increased, although to a greater extent, by cyanobacteria. However, the brown pigments of diatoms (mainly fucoxanthin) suppressed the bluish-green color of cyanobacteria, which can also be seen on the images of the biofilms (Figure S1). Coccoid unicellular species among cyanobacteria and Achnanthidium exiguum among diatoms were present in outstanding amounts. The $7.1 \times 10^{-6 \%}$ essential oil concentration caused a further but non-significant decrease in the proportion of green algae (Figure $5 b$ ), i.e., the green color appearing in the biofilm cannot be related to green algae, as it was assumed. It could be observed in the $1.8 \times 10^{-6} \%$ treatment that the large presence of cyanobacteria can also be masked by the brown color of "healthy" diatoms present in a similar proportion. Based on microscopic observations and quantitative data, the green color observed during the 7.1 $\times 10^{-6 \%}$ treatment is partly due to the presence of cyanobacteria, but more to the fall of diatoms and the degradation of their brown pigments. A further increase in the essential oil concentration caused an additional but not significant decrease in the proportion of green algae and even cyanobacteria (Figure $5 b$ ). The proportion of diatoms was higher compared to the previous treatments, although the difference was not significant. The pale green color of the biofilm at the end of the exposure is thus partly due to the presence of cyanobacteria and partly due to the diatoms that have lost their brown pigments.
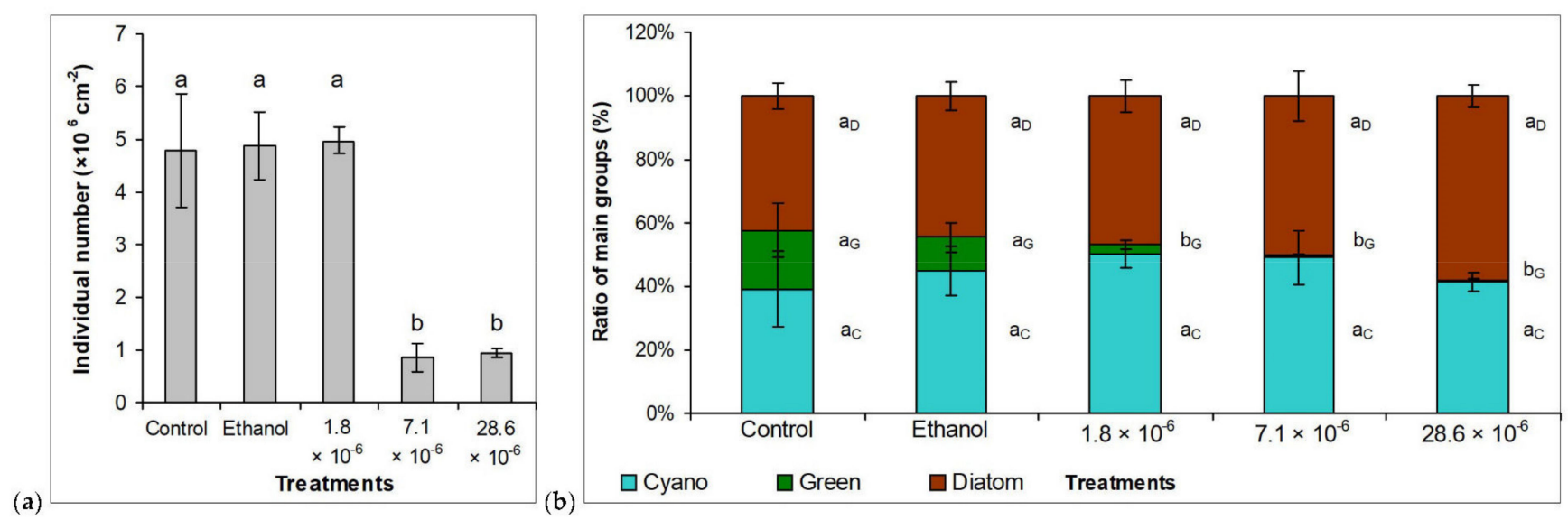

Figure 5. (a) The individual number per unit area and (b) proportion of the major groups (cyanobacteria, diatoms, green algae) in control and differently treated biofilms on the $6^{\text {th }}$ week of the experiment. Control: untreated biofilm. Ethanol: the culturing medium contained $28.6 \times 10^{-6} \%(\mathrm{v} / \mathrm{v})$ ethanol. 1.8, 7.1, and $28.6 \times 10^{-6}$ : the applied essential oil concentrations $(\%, v / v ;$ dissolved in ethanol). Mean values and standard deviations are indicated $(n=3)$. Lowercase letters indicate significant differences.

\section{Discussion}

Although antimicrobial activities of GLS and their hydrolysis products, especially ITCs, are quite well known [49,51], we did not find relevant literature data about the algaecide effects of these compounds. As our results show, acute treatment can significantly reduce the viability of all the tested cyanobacteria and eukaryotic algae. Cyanobacteria seemed to be less sensitive to the treatments both on the basis of chlorophyll contents and $\mathrm{EC}_{50}$ values. Synechococcus was less sensitive than the other studied cyanobacteria. Exact explanations of these phenomena require further investigations. What is currently can be concluded from the literature data is that some bacteria have a higher sensitivity to different ITCs than others [51], and their sensitivity seems not to be related to their morphology, cell wall structure, or physiological activity. In the case of the tested Synechococcus elongatus strain, one reason for lower sensitivity could be the fast proliferation of the species. The higher 
sensitivity of eukaryotes was also observed among non-photosynthetic microbes: AITC and PEITC severely inhibited certain yeasts and filamentous fungi. At the same time, the same concentration was not effective on certain Gram-positive and Gram-negative bacteria [52]. The mechanism behind the antimicrobial activities of ITCs is far from clear. It was not even precisely outlined whether ITCs exert their effects inside the prokaryotic and eukaryotic cells or their effect on cell membranes. It was observed that AITC is able to create pores on the bacterial cell membrane inducing membrane leakage [53], and inside the cells, AITC is able to react with many substances [54]. Intracellular accumulation of reactive oxygen species (ROS) and mitochondrial membrane depolarization as main effects were reported in the case of fungal cells treated with ITCs (AITC, PEITC, and benzyl-ITC - BITC; [55]). The most likely targets of ITCs are molecules with thiol groups, many of them responsible for redox homeostasis of the cells, which means that oxidative stress seems to be the main background of antimicrobial (antifungal) activity [49]. The higher sensitivity of cyanobacteria to the accumulation of ROS, especially hydrogen peroxide compared to eukaryotic algae, is known [56], although our laboratory experiments suggest that the effects of ITCs have a more complex background besides generating oxidative stress, or the caused oxidative stress did not result in accumulation of hydrogen peroxide. Low persistency of ITCs also supports growth recovery similarly to the observations about fungi [49]. However, on the basis of the results, there is no doubt about the broad algicide spectrum of horseradish essential oil.

Results of microcosm experiments with natural phytoplankton assemblages show that horseradish essential oil from $7.1 \times 10^{-6} \%(\mathrm{v} / \mathrm{v})$ is applicable to push back phytoplankton proliferation even in natural assemblages. The relatively weaker effect on microcosm could be explained by the organic matter content of the natural system: it was observed that the presence of organic compounds could have a serious negative impact on the antimicrobial activity of ITCs [49]. Relative abundance changes of the main taxonomical groups were chosen to assess compositional changes in microcosms. Relative abundances reflect the changes of individual numbers directly; moreover, these data hold extra information about the changes of the whole algal assemblages. They have ecological information besides the "technical" data of individual number changes. These data show not just the decreases or increases of a given group, but they show proportional changes of the assemblages in a more direct way than individual numbers. The most striking result of the microcosm experiment was the fall of the relative abundance of one group of cyanobacteria, Cyano 1, with species belonging to the order Synechococcales (Figure 3a). So, despite the result that Synechococcus elongatus itself was the least sensitive among the tested laboratory strains, it could be pushed out from an assemblage. Since the environmental circumstances were favorable for cyanobacterial growth, initial dominance relations (green algal dominance) and interspecific interactions could be the background of the results contrary to observations in the laboratory. This result suggests that the composition of the assemblages has a strong influence on the effects of a toxic substance, as it was observed in the case of fungal assemblages [49] and in our former microcosm studies [57]. However, this result also highlights that there is the possibility to achieve satisfactory results with the application of the horseradish essential oil, even in the case of species that showed tolerance in the laboratory. The microcosm systems (and the pond itself) can be considered as eutrophic or at least meso-eutrophic ones based on their chlorophyll-a contents [58,59]. This state did not change during the treatments, so the applied concentrations of horseradish oil had longer-term effects than aluminum or iron applied for phosphorous removal or calcium and magnesium also for phosphorous removal or as carbonates for precipitation $[2,60]$. On the other hand, the disadvantages of the mentioned methods (toxicity, $\mathrm{pH}$ influence, increase in water hardness, or production of undesirable sludge [17]) cannot be expected with using horseradish oil. However, the specification of possible side effects undoubtedly requires further investigations.

In contrast to microcosm experiments (phytoplankton assemblages), green algae showed low resistance against the treatments in the biofilm experiments. Indeed, cyanobac- 
teria and diatoms are among early colonizers, which play a significant role in biofilm development [35]. Certain diatoms are able to settle even on the most fouling-resistant surfaces [61], so it is not a surprise that the dominant, but rather planktic green algal species (T. obliquus) was pushed back already at the lowest applied horseradish essential oil concentration $\left(1.8 \times 10^{-6} \%\right)$. The individual number dropped down to one-fifth of the original individual number in the biofilm, so the $7.1 \times 10^{-6 \%}$ and higher concentration can be considered as a successful treatment against biofouling. As the results show, the remaining individuals were cyanobacteria and diatoms. The viability of the latter group is questionable because of the lack of associated xanthophylls, which are essential to the healthy physiology of these microalgae [62]. To compare the effectiveness of the applied horseradish essential oil with other compounds derived from natural sources would be too early at the current state of research. There are several compounds isolated from macroalgae (e.g., cystochloroketals [63]; chromanols [64]; alcaloids; phenolic acids [65]; dopamine [66]), but also many different extracts [67-71] with proved anti-algal and anticyanobacterial activities. There are also many types of extracts from microalgae with similar activities [72-77]. The huge advantage of plant-derived essential oils - including horseradish essential oil - is that they are renewable in nature, relatively inexpensive, available in commercial quantities (because of the food or medicine industrial background), and could have minimal toxicity (among others because of their low persistency [49]) compared to many conventionally applied chemicals [36].

\section{Materials and Methods}

\subsection{Strains, Culturing Conditions, and Laboratory Experimental Setup}

The cyanobacteria and eukaryotic algae strains used during the work, the culturing media used for their maintenance and for the experiments, and the experimental conditions are summarized in Table 2. During the experiments, the preferences of the used cyanobacterial and eukaryotic algal strains were taken into consideration. Different culturing media and temperatures were used because of the different optima of cyanobacteria and eukaryotic algae (most relevant with C. ovata).

For the determination of isothiocyanates in the applied horseradish essential oil, the GC-MS method described in the work of [78] was used. A $1 \mathrm{uL}$ aliquot of pure horseradish essential oil, 100-fold diluted with acetone, was injected and analyzed at 1:100 split. Two main components covered the ITC content of the horseradish essential oil used for the study $(87.7 \% \pm 1.34 \%$ AITC and $2.68 \% \pm 1.34 \%$ PEITC; Figure S2). Ethanol was used for the dilution of the essential oil. The exact amounts of the two main components in the different treatments are shown in Table 3. To check the possible effects of the diluent, cultures containing only ethanol were also applied. Control cultures were prepared without ethanol and/or essential oil. Treated cultures were supplemented with essential oil diluted in ethanol or with pure essential oil at the inoculation to reach 1.8, 3.6, 7.1, 14.3, and $28.6 \times 10^{-6 \%}(\mathrm{v} / \mathrm{v})$ essential oil concentrations. The exposure time was 7 days for cyanobacteria and D. salina and 14 days for other eukaryotic algae. The growth of the cultures was monitored by measuring the chlorophyll content. Samples of $200 \mu \mathrm{L}$ were collected daily for the measurements. Chlorophyll content was calculated on the basis of absorbance measured in $80 \%$ acetone at $663 \mathrm{~nm}$ [79]. Spectrophotometric measurements were performed with a Hach Lange DR 6000 UV/VIS spectrophotometer (Hach Lange $\mathrm{GmbH}$, Düsseldorf, Germany).

To provide the essential oil concentrations causing 50\% growth inhibition ( $\mathrm{EC}_{50}$ values), the extent of growth inhibition (in percentage compared to control) was plotted as a function of essential oil concentrations. Trend lines were fitted to the obtained curves (second-order relationship), and from the equations of the trend lines (quadratic equations), the concentrations causing 50\% inhibition were calculated. 
Table 2. Culturing conditions of cyanobacteria and eukaryotic algae isolates used to study the algaecide effect of horseradish essential oil.

\begin{tabular}{|c|c|c|}
\hline Prokaryotes & Culturing Medium & Culture Parameters \\
\hline $\begin{array}{c}\text { Synechococcus elongatus } \\
\text { Microcystis aeruginosa } \\
\text { Cylindrospermopsis raciborskii }\end{array}$ & $\begin{array}{l}\text { Allen Medium [80] } \\
\text { Allen Medium (without nitrate) }\end{array}$ & $\begin{array}{l}100 \mathrm{~mL} \text { Erlenmeyer flask on shaker }(90 \mathrm{rpm}) \text {, } \\
35 \mathrm{~mL} \text { final volume, } 28^{\circ} \mathrm{C} \text {, continuous } \\
\text { irradiation }\left(80 \mu \mathrm{mol} \text { photons } \mathrm{m}^{-2} \mathrm{~s}^{-1}\right) \text {. }\end{array}$ \\
\hline \multicolumn{3}{|l|}{ Eukaryotes } \\
\hline Dunaliella salina & Johnson's Medium [81] & $\begin{array}{l}100 \mathrm{~mL} \text { Erlenmeyer flask on shaker }(90 \mathrm{rpm}) \text {, } \\
35 \mathrm{~mL} \text { final volume, } 28^{\circ} \mathrm{C} \text {, continuous } \\
\text { irradiation }\left(80 \mu \mathrm{mol} \text { photons } \mathrm{m}^{-2} \mathrm{~s}^{-1}\right) \text {. }\end{array}$ \\
\hline $\begin{array}{l}\text { Cryptomonas ovata } \\
\text { Chorella sorokiniana } \\
\text { Chlorococcum } \mathrm{sp.} \\
\text { Desmodesmus communis }\end{array}$ & Bold's Basal Medium [83] & $\begin{array}{l}100 \mathrm{~mL} \text { Erlenmeyer flask on shaker (90 rpm), } \\
50 \mathrm{~mL} \text { final volume, } 24^{\circ} \mathrm{C} \text {, continuous } \\
\text { irradiation }\left(40 \mu \mathrm{mol} \text { photons } \mathrm{m}^{-2} \mathrm{~s}^{-1}\right) \text {. }\end{array}$ \\
\hline
\end{tabular}

Table 3. Horseradish essential oil concentrations (v/v \%) in the different treatments and the allyl-isothiocyanate (AITC) and phenethyl-isothiocyanate (PEITC) contents $(\mu \mathrm{M})$.

\begin{tabular}{ccc}
\hline $\begin{array}{c}\text { Treatments } \\
(\mathbf{v} / \mathbf{v} \% \text { Horseradish Oil) }\end{array}$ & $\mu$ M AITC & $\mu$ PEITC \\
\hline $1.8 \times 10^{-6}$ & $0.78 \pm 0.012$ & $0.016 \pm 0.008$ \\
$3.6 \times 10^{-6}$ & $1.57 \pm 0.025$ & $0.032 \pm 0.016$ \\
$7.1 \times 10^{-6}$ & $3.13 \pm 0.05$ & $0.064 \pm 0.032$ \\
$14.3 \times 10^{-6}$ & $6.25 \pm 0.10$ & $0.128 \pm 0.064$ \\
$28.6 \times 10^{-6}$ & $12.51 \pm 0.20$ & $0.257 \pm 0.128$ \\
\hline
\end{tabular}

\subsection{Microcosm Experiments with Natural Phytoplankton Assemblages}

Microcosm experiments were established in summer at the Garden Pond in the Zoo of Debrecen, which is a shallow artificial ornamental pond (average depth: $0.35 \mathrm{~m}$, area: $\sim 50 \mathrm{~m}^{2}$ ), with a constant water level maintained by the introduction of tap water. There is potted vegetation on the shore and in the pond. The microcosm system developed by our workgroup $[63,84]$ was applied in triplicates with minor modifications (Figure S3): water samples from the pond were filled into borosilicate glass beakers ( 21 in each one). One beaker served as control (without the addition of ethanol or essential oil), one contained only ethanol in $28.6 \times 10^{-6} \%(\mathrm{v} / \mathrm{v})$, and the others were used to test five experimental treatments, containing $1.8,3.6,7.1,14.3$, and $28.6 \times 10^{-6} \%(\mathrm{v} / \mathrm{v})$ essential oil. The beakers were placed in plastic baskets, and the baskets were placed into the pond $20 \mathrm{~cm}$ deep. The baskets had thin translucent (polyester) tops to allow photosynthesis and gas exchange but prevent the beakers from damage (the distance between the water surface of the beakers and the translucent top was at least $8 \mathrm{~cm}$ ). There was no exchange between the beakers' contents and the pond water, but the baskets containing the beakers allowed the pond water to flow in and surround the beakers, resulting in efficient heat exchange with the pond. Environmental parameters (water temperature, $\mathrm{pH}$, conductivity, $\mathrm{O}_{2}$ concentration, and saturation) were measured by an HQ30d multimeter (Hach Lange GmbH, Düsseldorf, Germany) every $48 \mathrm{~h}$ during 14 days. Samples of $20 \mathrm{~mL}$ were collected at the same times from all microcosms for counting algal individuals, taxonomical identification, and chlorophyll-a measurements. The water level in the microcosms was maintained by adding tap water before sampling.

Aliquots of $5 \mathrm{~mL}$ were used for chlorophyll-a content measurements. Samples were centrifuged $(6000 \times g, 10 \mathrm{~min}$, Beckman Avanti J-25, Beckman Industries Inc., Fullerton, California, USA), the supernatants were removed, pellets were lyophilized (Christ Alpha 1e2 LD plusfreeze-dryer equipment, Martin Christ Gefriertrocknungsanlagen $\mathrm{GmbH}$, Osterode am Harz, Germany) and their weights were measured (Ohaus Adventurer ${ }^{\mathrm{TM}}$ Pro analytical scale, 
Ohaus Corporation, Parsippany, New Jersey, USA). The chlorophyll-a content of the weighted pellets was measured spectrophotometrically using the hot methanolic extraction method [64]. To provide the essential oil concentrations causing $50 \%$ growth inhibition ( $\mathrm{EC}_{50}$ values), the same method was applied as in the case of laboratory experiments. Aliquots of $15 \mathrm{~mL}$ of the collected samples were stored in Lugol's solution for taxa identification and counting the number of algal individuals. The samples were processed according to the European Standard EN 15204:2006 [85]. An Olympus CKX31 reversed microscope and 400× magnification was used for counting and taxa identification. The limit of detection was $0.7 \times 10^{6}$ individuals per liter. The identified taxa in natural assemblages (microcosms) were taxonomically grouped using AlgaeBase [86], and relative abundances were calculated. Relative taxa were grouped together, all in all, the following eight groups were created (each with higher relative abundances than 3\% at some time of the exposition): Cyano 1 and 2 (Synechococcales and Chroococcales, respectively); Diatom 1 and 2 (Bacillariophyceae and Mediophyceae, respectively) and Green 1-4 (Trebouxiophyceae, Chlorophyceae, Conjugatophyceae, and Carophyceae + Klebsormidiophyceae, respectively).

\subsection{Algal Biofilm Experiments with Natural Benthic Algal Assemblages}

In algal biofilm experiments, a sample from natural biofilm formed in an aquaponic culture was used to produce the algae "coatings". The inoculum constituted $\sim 45 \%$ of diatoms, $\sim 45 \%$ unicellular coccoid cyanobacteria, and $\sim 10 \%$ coccoid green algae. Pieces of $5 \times 15 \mathrm{~cm}$ white tiles were used as model surfaces. The tiles were placed in glass tubs filled with Jaworski's Medium [82] and kept at room temperature $\left(\sim 23^{\circ} \mathrm{C}\right)$ under natural irradiation. The tubs were covered with transparent plastic (polyester) lids to minimize evaporation. After the development of biofilms (after 4 weeks), the tiles were placed into glass tubs filled with Jaworski's Medium [82] without essential oil (control) and with 1.8, 7.1, and $28.6 \times 10^{-6} \%(\mathrm{v} / \mathrm{v})$ essential oil dissolved in ethanol. The time of the exposition was 6 weeks. At the end of the exposure time, the biofilms were removed from the entire surfaces $\left(75 \mathrm{~cm}^{2}\right.$ per tile) with a fine-edged spatula, resuspended in 20 $\mathrm{mL}$ of culturing medium, and preserved with Lugol's solution. Algal individuals were counted and identified from the preserved samples by the same method as it is described in the case of microcosm experiments. Knowing the individual numbers, it was possible to characterize the quantitative relations of the biofilms to a given surface. To provide the essential oil concentrations causing $50 \%$ growth inhibition ( $\mathrm{EC}_{50}$ values), the same method was applied as in the case of laboratory and microcosm experiments.

\subsection{Data Analyses}

All experiments were performed in triplicates (as single experiments with 3 repetitions of all individual groups). Analysis of covariance of means of chlorophyll content data (one-way ANCOVA, Past 2.17b, [87]) was used to show differences among the growth trends of control and treated cultures or assemblages.

To present the compositional changes, individual number data of the groups were averaged within the three replicates, two-way analysis of variance (two-way ANOVA, Past $2.17 \mathrm{~b}$ [87]) with Tukey post-hoc test was applied to evaluate the differences among relative abundances in time and of the certain composition of control and treated assemblages.

Analysis of variance (one-way ANOVA, Past 2.17b [87]) with Tukey post-hoc test was applied to evaluate the differences among individual numbers and composition of control and treated biofilms.

\section{Conclusions}

Increased proliferation of algae: blooms of planktic species or biofouling by benthic ones is a current problem in natural as well as in artificial water bodies. Effective handling of these phenomena becomes more and more urgent. Chemicals derived from natural sources, which could be effective in low concentrations and are biodegradable, may have an advantage over conventional chemical treatments [17]. In this study, the anti-algal 
effects of AITC- and PEITC-containing horseradish essential oil were tested in laboratory experiments, on natural phytoplankton assemblages, and on semi-artificial biofilm. The results show that acute treatment can significantly reduce the viability of laboratory strains of potentially bloom-forming cyanobacteria and eukaryotic algae. Results of microcosm experiments with natural phytoplankton assemblages show that horseradish essential oil from $7.1 \times 10^{-6} \%(\mathrm{v} / \mathrm{v})$ is applicable to push back phytoplankton proliferation even in natural assemblages. The regeneration ability of the assemblages suggests the necessity of weekly treatment for successful control of phytoplankton proliferation. In the biofilm, the individual number was dropped down to one-fifth of the original individual number, so $7.1 \times 10^{-6} \%(\mathrm{v} / \mathrm{v})$ and higher concentration of the essential oil can be considered as successful treatment also against biofouling. Horseradish is well known, widely used with a well-established industrial background $[40,88]$. The essential oil used in this study can be produced even from processed horseradish vegetable waste [89], so it can be a promising basis for the development of anti-algal products from natural sources.

Supplementary Materials: The following are available online at https://www.mdpi.com/article/ 10.3390/plants10081550/s1, Table S1: The most commonly observed genera or species in the microcosms (with higher relative abundances than $3 \%$ of the corresponding taxa at some time of the exposition. Figure S1: Development of biofilms in (a) control and in (b) $1.8 \times 10^{-6}$; (c) $7.1 \times 10^{-6}$; and (d) $28.6 \times 10^{-6} \%(\mathrm{v} / \mathrm{v})$ horseradish essential oil treatment during six weeks exposition, Figure S2: Chromatogram of the horseradish essential oil used in the study. AITC: Allyl-isothiocyanate, PEITC: phenethyl-isothiocyanate, Figure S3: Sketch of the experimental setup in microcosm experiments.

Author Contributions: Conceptualization, G.V. and I.B.; methodology, G.V., I.B., and S.G.; formal analysis, I.B., V.B.-B., and Z.N.-K.; investigation, I.B. and V.B.-B.; resources, G.V. and S.G.; data curation, I.B.; writing—original draft preparation, I.B.; writing—review and editing, G.V., S.G., and V.B.-B.; visualization, I.B. and V.B.-B.; supervision, G.V.; project administration, G.V. and S.G.; funding acquisition, G.V., S.G., and I.B. All authors have read and agreed to the published version of the manuscript.

Funding: The research was funded by the Norway Grant HU09-0009-A2-2013. Authors were financially supported by the National Research, Development and Innovation Office - NKFIH FK 128 021 (S.G.), FK 131917 (I.B.), FK 132142 (V.B-B.) grants; by the János Bolyai Research Scholarship of the Hungarian Academy of Sciences BO-00458-20-8 (V.B-B.); and by the ÚNKP-20-5 New National Excellence Program of the Ministry for Innovation and Technology from the Source of the National Research, Development and Innovation Fund (V.B-B.). Project no. TKP2020-IKA-04 has been implemented with the support provided by the National Research, Development and Innovation Fund of Hungary, financed under the 2020-4.1.1-TKP2020 funding scheme.

Data Availability Statement: The data presented in this study are available on request from the corresponding author.

Acknowledgments: We would like to thank the Director of the Zoo of Debrecen, Gergely Sándor Nagy, for the possibility to achieve the experiments at the garden pond.

Conflicts of Interest: The authors declare no conflict of interest. The funders had no role in the design of the study; in the collection, analyses; or interpretation of data; in the writing of the manuscript, or in the decision to publish the results.

\section{References}

1. Carpenter, S.R.; Caraco, N.F.; Correll, D.L.; Howarth, R.W.; Sharpley, A.N.; Smith, V.H. Nonpoint pollution of surface waters with phosphorus and nitrogen. Ecol. Appl. 1998, 8, 559-568. [CrossRef]

2. Jančula, D.; Marsalek, B. Critical review of actually available chemical compounds for prevention and management of cyanobacterial blooms. Chemosphere 2011, 85, 1415-1422. [CrossRef] [PubMed]

3. Qi, S.-H.; Ma, X. Antifouling compounds from marine invertebrates. Mar. Drugs 2017, 15, 263. [CrossRef]

4. Yebra, D.M.; Kiil, S.; Dam-Johansen, K. Antifouling technology-Past, present and future steps towards efficient and environmentally friendly antifouling coatings. Prog. Org. Coatings 2004, 50, 75-104. [CrossRef]

5. Mohamed, Z.A. Alum and lime-alum removal of toxic and nontoxic phytoplankton from the Nile river water: Laboratory study. Water Resour. Manage. 2001, 15, 213-221. [CrossRef] 
6. Auvray, F.; van Hullebusch, E.D.; Deluchat, V.; Baudu, M. Laboratory investigation of the phosphorus removal (SRP and TP) from eutrophic lake water treated with aluminium. Water Res. 2006, 40, 2713-2719. [CrossRef]

7. Meers, E.; Rousseau, D.P.L.; Lesage, E.; Demeersseman, E.; Tack, F.M.G. Physico-chemical P removal from the liquid fraction of pig manure as an intermediary step in manure processing. Water Air Soil Pollut. 2006, 169, 317-330. [CrossRef]

8. Takacs, I.; Murthy, S.; Smith, S.; McGrath, M. Chemical phosphorus removal to extremely low levels: Experience of two plants in the Washington, DC area. Water Sci. Technol. 2006, 53, 21-28. [CrossRef]

9. Lelkova, E.; Rulik, M.; Hekera, P.; Dobias, P.; Dolejs, P.; Borovickova, M.; Poulickova, A. The influence of the coagulant PAX-18 on Planktothrix agardhii bloom in a shallow eutrophic fishpond. Fottea 2008, 8, 147-154. [CrossRef]

10. Jiang, J.Q.; Graham, N.J.D.; Harward, C. Comparison of polyferric sulfate with other coagulants for the removal of algae and algae-derived organic-matter. Water Sci. Technol. 1993, 27, 221-230. [CrossRef]

11. Chow, C.W.K.; House, J.; Velzeboer, R.M.A.; Drikas, M.; Burch, M.D.; Steffensen, D.A. The effect of ferric chloride flocculation on cyanobacterial cells. Water Res. 1998, 32, 808-814. [CrossRef]

12. Briley, D.S.; Knappe, D.R.U. Optimizing ferric sulfate coagulation of algae with streaming current measurements. J. Am. Water Works Ass. 2002, 94, 80-90. [CrossRef]

13. Dafforn, K.A.; Lewis, J.A.; Johnston, E.L. Antifouling strategies: History and regulation, ecological impacts and mitigation. Mar. Pollut. Bull. 2011, 62, 453-465. [CrossRef] [PubMed]

14. Blomqvist, P. Late summer phytoplankton responses to experimental manipulations of nutrients and grazing in unlimed and limed Lake Njupfatet, central Sweden. Archiv Für Hydrobiol. 1996, 137, 425-455. [CrossRef]

15. Prepas, E.E.; Pinel-Alloul, B.; Chambers, P.A.; Murphy, T.P.; Reedyk, S.; Sandland, G.; Serediak, M. Lime treatment and its effects on the chemistry and biota of hardwater eutrophic lakes. Freshw. Biol. 2001, 46, 1049-1060. [CrossRef]

16. Zhang, Y.; Ghadouani, A.; Prepas, E.E.; Pinel-Alloul, B.; Reedyk, S.; Chambers, P.A.; Robarts, R.D.; Methot, G.; Raik, A.; Holst, M. Response of plankton communities to whole-lake $\mathrm{Ca}(\mathrm{OH})_{2}$ and $\mathrm{CaCO}_{3}$ additions in eutrophic hardwater lakes. Freshw. Biol. 2001, 46, 1105-1119. [CrossRef]

17. Huh, J.-H.; Ahn, J.-W. A perspective of chemical treatment for cyanobacteria control toward sustainable freshwater development. Environ. Eng. Res. 2017, 22, 1-11. [CrossRef]

18. Omae, I. Organotin antifouling paints and their alternatives. Appl. Organomet. Chem. 2003, 17, 81-105. [CrossRef]

19. Amara, I.; Miled, W.; Slama, R.B.; Ladhari, N. Antifouling processes and toxicity effects of antifouling paints on marine environment. A review. Environ. Toxicol. Phar. 2018, 57, 115-130. [CrossRef]

20. Jančula, D.; Drabkova, M.; Cerny, J.; Karaskova, M.; Korinkova, R.; Rakusan, J.; Marsalek, B. Algicidal activity of phthalocyaninesscreening of 31 compounds. Environ. Toxicol. 2008, 23, 218-223. [CrossRef]

21. Jančula, D.; Marsalek, B.; Novotna, Z.; Cerny, J.; Karaskova, M.; Rakusan, J. In search of the main properties of phthalocyanines participating in toxicity against cyanobacteria. Chemosphere 2009, 77, 1520-1525. [CrossRef]

22. Shen, Q.; Zhu, J.; Cheng, L.; Zhang, J.; Zhang, Z.; Xu, X. Enhanced algae removal by drinking water treatment of chlorination coupled with coagulation. Desalination 2011, 271, 236-240. [CrossRef]

23. Junli, H.; Li, W.; Nenqi, R.; Li, L.X.; Fun, S.R.; Guanle, Y. Disinfection effect of chlorine dioxide on viruses, algae and animal planktons in water. Water Res. 1997, 31, 455-460. [CrossRef]

24. Chen, J.-J.; Yeh, H.-H. The mechanisms of potassium permanganate on algae removal. Water Res. 2005, 39, 4420-4428. [CrossRef] [PubMed]

25. Chen, J.-J.; Yeh, H.-H.; Tseng, I.-C. Potassium permanganate as an alternative preoxidant for enhancing algal coagulation-pilot and bench scale studies. Environ. Technol. 2008, 29, 721-729. [CrossRef] [PubMed]

26. Xie, P.; Ma, J.; Fang, J.; Guan, Y.; Yue, S.; Li, X.; Chen, L. Comparison of permanganate preoxidation and preozonation on algae containing water: Cell integrity, characteristics, and chlorinated disinfection byproduct formation. Environ. Sci. Technol. 2013, 47, 14051-14061. [CrossRef] [PubMed]

27. Plummer, J.D.; Edzwald, J.K. Effect of ozone on algae as precursors for trihalomethane and haloacetic acid production. Envion. Sci. Technol. 2001, 35, 3661-3668. [CrossRef]

28. Schrader, K.K.; Rimando, A.M.; Tucker, C.S.; Glinski, J.; Cutler, S.J.; Cutler, H.G. Evaluation of the natural product SeaKleen for controlling the musty-odorproducing cyanobacterium Oscillatoria perornata in catfish ponds. North Am. J. Aquacul. 2004, 66, 20-28. [CrossRef]

29. USEPA 2005. Reregistration Eligibility Decision for Endothall; EPA 738-R-05-008; United States Environmental Protection Agency, Prevention, Pesticides and Toxic Substances (7508C): Washington, DC, USA, 2005.

30. Giacomazzi, S.; Cochet, N. Environmental impact of diuron transformation: A review. Chemosphere 2004, 56, 1021-1032. [CrossRef]

31. Osano, O.; Admiraal, W.; Klamer, H.J.C.; Pastor, D.; Bleeker, E.A.J. Comparative toxic and genotoxic effects of chloroacetanilides, formamidines and their degradation products on Vibrio fischeri and Chironomus riparius. Environ. Pollut. 2002, 119, 195-202. [CrossRef]

32. Holdren, C.; Jones, W.; Taggart, J. Managing Lakes and Reservoirs; North American Lake Management Society and Terrene Institute: Madison, WI, USA, 2001.

33. Dahms, H.U.; Dobretsov, S. Antifouling compounds from marine macroalgae. Marine Drugs 2017, 15, 265. [CrossRef] [PubMed]

34. Wang, K.-L.; Wu, Z.-H.; Wang, C.-Y.; Xu, Y. Mini-review: Antifouling natural products from marine microorganisms and their synthetic analogs. Marine Drugs 2017, 15, 266. [CrossRef] [PubMed] 
35. Saha, M.; Goecke, F.; Bhadury, P. Minireview: Algal natural compounds and extracts as antifoulants. J. Appl. Phycol. 2018, 30, 1859-1874. [CrossRef]

36. Al-Jumaili, A.; Kumar, A.; Bazaka, K.; Jacob, M.V. Plant secondary metabolite-derived polymers: A potential approach to develop antimicrobial films. Polymers 2018, 10, 515. [CrossRef] [PubMed]

37. Hasan, J.; Crawford, R.J.; Ivanova, E.P. Antibacterial surfaces: The quest for a new generation of biomaterials. Trends Biotechnol. 2013, 31, 295-304. [CrossRef]

38. Nazzaro, F.; Fratianni, F.; De Martino, L.; Coppola, R.; De Feo, V. Effect of essential oils on pathogenic bacteria. Pharmaceuticals 2013, 6, 1451-1474. [CrossRef]

39. Andrade, B.F.M.T.; Barbosa, L.N.; da Silva Probst, I.; Júnior, A.F. Antimicrobial activity of essential oils. J. Essent. Oil Res. 2014, 26, 34-40. [CrossRef]

40. Nguyen, N.M.; Gonda, S.; Vasas, G. A review on the phytochemical composition and potential medicinal uses of horseradish (Armoracia rusticana) root. Food Rev. Int. 2013, 29, 261-275. [CrossRef]

41. Fahey, W.; Zalemann, A.T.; Talalay, P. The chemical diversity and distribution of glucosinolates and isothiocyanates among plants. Phytoehemistry 2000, 56, 5-51. [CrossRef]

42. Li, X.; Kushad, M.M. Purification and characterization of myrosinase from horseradish (Armoracia rusticana) roots. Plant Physiol. Biochem. 2005, 43, 503-511. [CrossRef]

43. Bones, A.M.; Rossiter, J.T. The enzymatic and chemically induced decomposition of glucosinolates. Phytochemistry 2006, 67, 1053-1067. [CrossRef]

44. Vig, A.P.; Rampai, G.; Thind, T.S.S.; Arora, S. Bio-protective effects of glucosinolates. LWT Food Sei. Technol. 2009, 42, 1561-1572. [CrossRef]

45. Kojima, M.; Oawa, K. Studies on the effect of isothiocyanates and their analogues on microorganisms. J. Ferment. Technol. 1971, 49, 740-746.

46. Zsolnai, T. Antimicrobial effect of thiocyanates and isothiocyanates. Arzneimittelforschung 1971, 21, 121-127.

47. Shin, I.S.; Masuda, H.; Naohide, K. Bactericidal activity of wasabi (Wasabia japonica) against Helicobacter pylori. Int. J. Food Microbiol. 2004, 94, 255-261. [CrossRef]

48. Luciano, F.B.; Holley, R.A. Enzymatic inhibition by allyl isothiocyanate and factors affecting its antimicrobial action against Escherichia coli OI57:H7. Int. J. Food Microbiol. 2009, 131, 240-245. [CrossRef] [PubMed]

49. Plaszkó, T.; Szúcs, Z.; Vasas, G.; Gonda, S. Effects of glucosinolate-derived isothiocyanates on fungi: A comprehensive review on direct effects, mechanisms, structure-activity relationship data and possible agricultural applications. J. Fungi 2021, 7, 539. [CrossRef]

50. Kassie, F.; Knasmuller, S. Genotoxic effects of allyl isothiocyanate and phenyl isothiocyanate. Chem. Biol. Interact. 2000, 127, 163-180. [CrossRef]

51. Saladino, F.; Bordin, K.; Luciano, F.B.; Franzón, M.F.; Mañes, J.; Meca, G. Antimicrobial activity of the glucosinolates. In Glucosinolates; Reference Series in Phytochemistry; Mérillon, J.-M., Ramawat, K.G., Eds.; Springer International Publishing: Cham, Switzerland, 2017.

52. Zsolnai, T. Antimicrobial effect of thiocyanates and isothiocyanates. Arztl. Forsch. 1966, 16, 870-876.

53. Lin, C.M.; Kim, J.; Du, W.X.; Wei, C.I. Bactericidal activity of isothiocyanate against pathogens on fresh produce. J. Food Prot. 2000, 63, 25-30. [CrossRef] [PubMed]

54. Hyldgaard, M.; Mygind, T.; Meyer, R.L. Essential oils in food preservation: Mode of action; synergies; and interactions with food matrix components. Front. Microbiol. 2012, 3, 1-24. [CrossRef]

55. Calmes, B.; Guyen, G.N.; Durmur, J.; Brisach, C.A.; Campion, C.; Iacomi, B.; Pigné, S.; Dias, E.; Macherel, D.; Guillemette, T.; et al. Glucosinolate-derived isothiocyanates impact mitochondrial function in fungal cells and elicit an oxidative stress response necessary for growth recovery. Front. Plant Sci. 2015, 6, 1-14. [CrossRef] [PubMed]

56. Weenink, E.F.J.; Luimstra, V.M.; Schuurmans, J.M.; Van Herk, M.J.; Visser, P.M.; Matthijs, H.C.P. Combatting cyanobacteria with hydrogenperoxide: A laboratory study on the consequences for phytoplankton community and diversity. Front. Microbiol. 2015, 6, 714. [CrossRef]

57. Bácsi, I.; Gonda, S.; B-Béres, V.; Novák, Z.; Nagy, S.A.; Vasas, G. Alterations of phytoplankton assemblages treated with chlorinated hydrocarbons: Effects of dominant species sensitivity and initial diversity. Ecotoxicology 2015, 24, 823-834. [CrossRef] [PubMed]

58. Felföldy, L. Water Management Hydrobiology 16: Biological Water Quality Assessment. (Vizügyi Hidrobiológia 16: A Biológiai Vízminősités); Institute of Water Management (Vízgazdálkodási Intézet): Budapest, Hungary, 1987; p. 258.

59. Borics, G. Phytoplankton Based Ecological Status Assesment of Surface Waters. (Felszini Vizek Fitoplankton Alapú Ökológiai Állapotértékelése); Hungarian Academy of Sciences; Centre for Ecological Research; Danube Research Institute; Department of Tisza Research: Debrecen, Hungary, 2015.

60. Ghernaout, B.; Ghernaout, D.; Saiba, A. Algae and cyanotoxins removal by coagulation/flocculation: A review. Desalin. Water Treat. 2010, 20, 133-143. [CrossRef]

61. Molino, P.J.; Wetherbee, R. The biology of biofouling diatoms and their role in the development of microbial slimes. Biofouling 2008, 24, 365-379. [CrossRef]

62. Van de Poll, W.H.; van Leeuwe, M.A.; Roggeveld, J.; Buma, A.G.J. Nutrient limitation and high irradiance acclimation reduce par and uv-induced viability loss in the antarctic diatom Chaetoceros brevis (Bacillariophyceae). J. Phycol. 2005, 41, 840-850. [CrossRef] 
63. Hattab, M.; Genta-Jouve, G.; Bouzidi, N.; Ortalo-Magné, A.; Hellio, C.; Maréchal, J.-P.; Piovetti, L.; Thomas, O.; Culioli, G. Cystophloroketals A-E; unusual phloroglucinol-meroterpenoid hybrids from the brown alga Cystoseira tamariscifolia. J. Nat. Prod. 2015, 78, 1663-1670. [CrossRef]

64. Cho, J. Antifouling chromanols isolated from brown alga Sargassum horneri. J. Appl. Phycol. 2013, 25, 299-309. [CrossRef]

65. Sun, Y.-Y.; Wang, H.; Guo, G.-L.; Pu, Y.-F.; Yan, B.-L.; Wang, C.-H. Green alga Ulva pertusa-A new source of bioactive compounds with antialgal activity. Environ. Sci. Pollut. Res. 2015, 22, 10351-10359.

66. Van Alstyne, K.L.; Harvey, E.L.; Cataldo, M. Effects of dopamine; a compound released by the green-tide macroalga Ulvaria obscura (Chlorophyta); on marine algae and invertebrate larvae and juveniles. Phycologia 2014, 53, 195-202. [CrossRef]

67. Silkina, A.; Bazes, A.; Mouget, L.; Bourgaugnon, N. Comparative efficiency of macroalgal extracts and booster biocides as antifouling agents to control growth of the diatom species. Mar. Pollut. Bull. 2012, 64, 2039-2046. [CrossRef]

68. Chambers, L.D.; Hellio, C.; Stokes, K.R.; Dennington, S.P.; Goodes, L.R.; Wood, R.J.K.; Walsh, F.C. Investigation of Chondrus crispus as a potential source of new antifouling agents. Int. Biodeter. Biodegr. 2011, 65, 939-946. [CrossRef]

69. Ktari, L.; Ismail-Ben Ali, A.; Ben Redjem, Y.; Langar, H.; Bour, M.E. Antifouling activity and chemical investigation of the brown alga Dictyota fasciola (Dictyotales) from Tunisian coast. Cah. Biol. Mar. 2010, 51, 109-115.

70. Águila-Ramírez, R.N.; Arenas-González, A.; Hernández-Guerrero, C.J.; González-Acosta, B.; Borges-Souza, J.M.; Verón, B.; Pope, J.; Hellio, C. Antimicrobial and antifouling activities achieved by extracts of seaweeds from gulf of California; Mexico. Hidrobiológica 2012, 22, 8-15.

71. Plouguerné, E.; Hellio, C.; Cesconetto, C.; Thabard, M.; Mason, K.; Véron, B.; Pereira, R.C.; Gama, B.A. Antifouling activity as a function of population variation in Sargassum vulgare from the littoral of Rio de Janeiro. J. Appl. Phycol. 2010, 22, 717-724. [CrossRef]

72. Ma, H.; Krock, B.; Tillmann, U.; Bickmeyer, U.; Graeve, M.; Cembella, A. Mode of action of membrane-disruptive lytic compounds from the marine dinoflagellate Alexandrium tamarense. Toxicon 2011, 58, 247-258. [CrossRef]

73. Poulson, K.L.; Sieg, R.D.; Prince, E.K.; Kubanek, J. Allelopathic compounds of a red tide dinoflagellate have species-specific and contextdependent impacts on phytoplankton. Mar. Ecol. Prog. Ser. 2010, 416, 69-78. [CrossRef]

74. Prince, E.K.; Poulson, K.L.; Myers, T.L.; Sieg, R.D.; Kubanek, J. Characterization of allelopathic compounds from the red tide dinoflagellate Karenia brevis. Harmful Algae 2010, 10, 39-48. [CrossRef]

75. Poulson-Ellestad, K.; McMillan, E.; Montoya, J.P.; Kubanek, J. Are offshore phytoplankton susceptible to Karenia brevis allelopathy? J. Plankton Res. 2014, 36, 1344-1356. [CrossRef]

76. Cai, Z.; Zhu, H.; Duan, S. Allelopathic interactions between the redtide causative dinoflagellate Prorocentrum donghaiense and the diatom Phaeodactylum tricornutum. Oceanologia 2014, 56, 639-650. [CrossRef]

77. Sala-Pérez, M.; Alpermann, T.J.; Krock, B.; Tillmann, U. Growth and bioactive secondary metabolites of arctic Protoceratium reticulatum (Dinophyceae). Harmful Algae 2016, 55, 85-96. [CrossRef]

78. Szúcs, Z.; Plaszkó, T.; Cziáky, Z.; Kiss-Szikszai, A.; Emri, T.; Bertóti, R.; Sinka, L.T.; Vasas, G.; Gonda, S. Endophytic fungi from the roots of horseradish (Armoracia rusticana) and their interactions with the defensive metabolites of the glucosinolate-myrosinaseisothiocyanate system. BMC Plant Biol. 2018, 18, 1-15. [CrossRef]

79. Bendall, D.S.; Bowes, J.M.; Stewart, A.C.; Taylor, M.E. Oxygen evolving photosystem II particles from Phormidium laminosum. Method. Enzymol. 1988, 167, 272-280.

80. Allen, M.M. Simple conditions for the growth of unicellular blue-green algae on plates. J. Phycol. 1968, 4, 1-4. [CrossRef] [PubMed]

81. Johnson, M.K.; Johnson, E.J.; MacElroy, R.D.; Speer, H.L.; Bruff, B.S. Effects of salts on the halophilic alga Dunaliella viridis. J. Bacteriol. 1968, 95, 1461-1468. [CrossRef]

82. CCAP Media Recipes. Available online: https://www.ccap.ac.uk/wp-content/uploads/MR_JM.pdf (accessed on 29 June 2021).

83. CCAP Media Recipes. Available online: https:/ /www.ccap.ac.uk/wp-content/uploads/MR_BB.pdf (accessed on 29 June 2021).

84. Bácsi, I.; B-Béres, V.; Kókai, Z.; Gonda, S.; Novák, Z.; Nagy, S.A.; Vasas, G. Effects of non-steroidal anti-inflammatory drugs on cyanobacteria and algae in laboratory strains and in natural algal assemblages. Environ. Poll. 2016, 212, 508-518. [CrossRef] [PubMed]

85. European Commitee for Standardizationrue. Water Quality e Guidance Standard on the Enumeration of Phytoplankton Using Inverted Microscopy (Utermöhl Technique); European Standard EN 15204: 2006; European Commitee for Standardizationrue: Brussels, Belgium, 2006.

86. Guiry, M.D.; Guiry, G.M. AlgaeBase. In World-Wide Electronic Publication; National University of Ireland: Galway, Ireland, 1996; Available online: http:/ / www.algaebase.org (accessed on 16 January 2021).

87. Hammer, O.; Harper, D.A.T.; Ryan, P.D. PAST: Paleontological statistics software package for education and data analysis. Palaeontol. Electron. 2001, 4, 9.

88. Papp, N.; Gonda, S.; Kiss-Szikszai, A.; Plaszkó, T.; Lőrincz, P.; Vasas, G. Ethnobotanical and ethnopharmacological data of Armoracia rusticana P. Gaertner, B. Meyer et Scherb. in Hungary and Romania: A case study. Genet. Resour. Crop. Evol. 2018, 65, 1893-1905. [CrossRef]

89. Norway Grant HU09-0009-A2-2013 Development and Production of Natural Bioactive Compound Based Products from Vegetable Waste of Horseradish Using Environmentally Friendly Technology. Available online: http://tormaolaj.hu/en/index.html (accessed on 16 January 2021). 